\title{
Thermodynamics Simulation Of Automobile Evaporative Air Conditioning System (Evaporative Test Rig) With Result And Discussion When Automobile Velocity Is $20 \mathrm{~km} / \mathrm{Hr}$.
}

\author{
R.Rajvaidya ${ }^{1}$, S.P.S. Rajput ${ }^{2}$ \\ I'Department of Mechanical, BUIT, BU, Bhopal, M.P, India) \\ ${ }^{2}$ (Department of Mechanical, MANIT, Bhopal, M.P, India)
}

\begin{abstract}
This paper presents the Thermodynamics simulation of automobile evaporative air conditioning system (evaporative test rig) when automobile velocity is $20 \mathrm{~K} . \mathrm{m} / \mathrm{hr}$ with result and discussion. Modeling of the thermodynamics process involves in evaporative test rig, as and when it is attach on automobile roof. Condition to be follow, is that velocity of automobile is $20 \mathrm{~K} . \mathrm{m} / \mathrm{hr}$. Simulation software develop simulation page that exhibits input button, calculations display, graphs and results of output condition.
\end{abstract}

Keywords- Dry bulb temperature, Evaporative test rig (E.T.R), Input feed value, Relative humidity Simulation software, Simulation page, Text box, Thermodynamics properties, velocity.

\section{Introduction}

Simulation software is based on the process of modeling a real evaporative test rig (E.T.R) attached on the roof of automobile which actuate a set of thermodynamics (psychrometric) formulas. It is, essentially, a program that allows us to observe an operation through simulation without actually performing that operation. Fig.2 display process flow of psychrometric formula for evaporative test rig. Simulation software's (Java script and HTML-canvas) are used to design equipment, so that the final result outcome will be as close to design specification as possible without expensive in process modification. A mock up of the actual control panel is connected to a real-time simulation of the physical response, giving valuable training experience without fear of a disastrous outcome. Automobile used under simulation is Wagon-R, on which evaporative test rig is installed. All the result are developed under a given condition that vehicle speed is $20 \mathrm{Km} / \mathrm{hr}$.

II. Software simulation to obtain the performance of Evaporative Test Rig, when the vehicle speed is restricted to $20 \mathrm{Km} / \mathrm{hr}$ by graphs and their results.

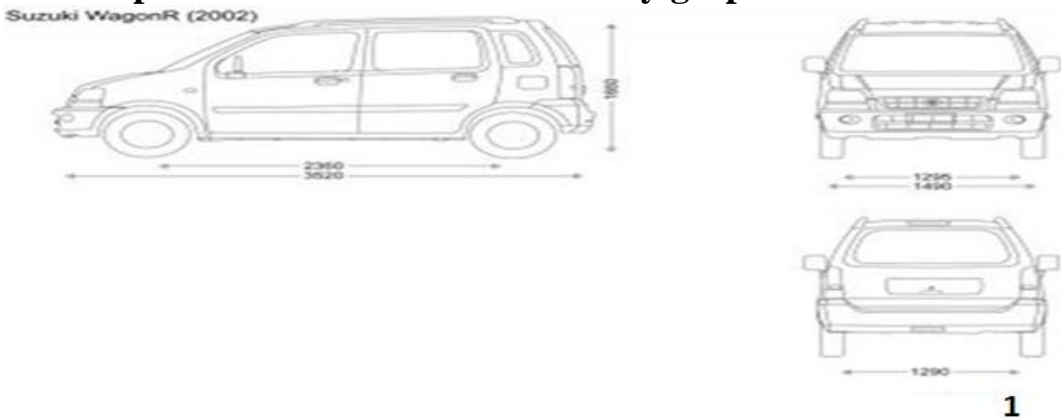

Figure: 1 .Side, front\&back view [1]

The website address[2] which provide inter-net access, on which simulation page[3]is created by using software tool's such as canvas HTML5[6] and Java script[7] .Simulation[3] of evaporative test rig loaded on automobile with formulation flow is indicated by arrow, from step 1 to step 6.The procedure for virtual simulation software development is as follows:

1.Picture of automobile loaded with evaporative test rig is drawn on Paint tool[4] of Microsoft windows software on computer. 


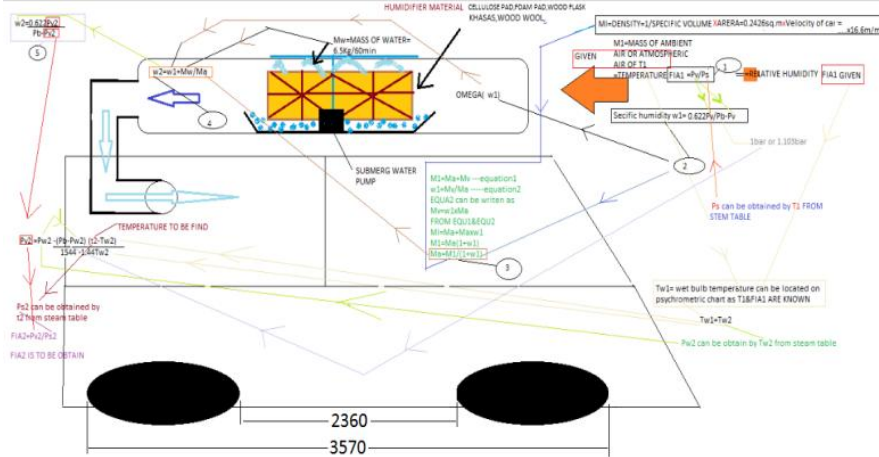

Figure: 2.Drawing Picture of Automobile(Wagon-R)Loaded with Evaporative Test Rig with Ambient Air flowing inside show indiviual formulation process 1 to process 6.

2.Formulation[5] flow with colourful arrow indication from initial step 1 to final step 6 in "Fig.2".

3.Text box[6] are created on the simulation page[3],these text box are for input value for the symbol like (Thermodynamic properties)temperature,relative humidity,velocity,etc with their unit. Text box are shown in "Fig3", below.
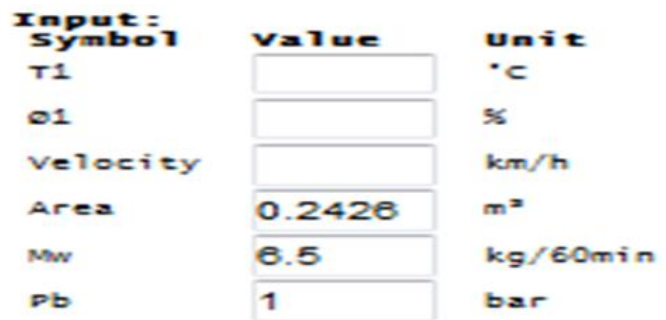

Figure:3.Displaying "Text box[6]for input symbol with there units".

4.After substituting the input values in text box,a command buttom as shown in " Fig 4" "RUN[6]" is pressed, it will display the "Result".

\section{Run!}

Figure: 4

5.For graphs,symbol like (Thermodynamic properties) dry bulb temperature,relative humidity,velocity,etc optionally opted in "Selection box[6]" or "drop down box[6]", as shown in the below "Fig.5" and "Fig.6".

\section{Symbol $\mathrm{T} 1$}

Figure:5.Selection box

\begin{tabular}{|c|c|}
\hline Symbol & T1 \\
\hline & $\mathrm{T} 1$ \\
\hline & $\varnothing 1$ \\
\hline & Velocity \\
\hline & Mw \\
\hline & $\mathrm{Pb}$ \\
\hline
\end{tabular}

Figure:6.Drop-down box,i.e.selection of T1.

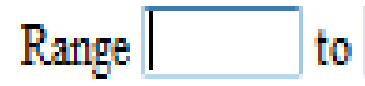

Figure:7. RangeText Box[6] for selected symbol.i.e.(T1).

\section{$\square \mathrm{Ps} \quad \square \mathrm{Pv} \quad \square \mathrm{Pa} \quad \square \mathrm{Vg} \quad \square \mathrm{M} 1 \square \mathrm{W} 1 \square \mathrm{Ma} \square \mathrm{W} 2 \square \mathrm{Pv} 2 \square \mathrm{ha} \quad \square \mathrm{hs} \quad \square \mathrm{h} \quad \square \mathrm{Tw} \quad \square \mathrm{Pw} \quad \square \mathrm{I} 2 \quad \square \mathrm{P} 2 \square \emptyset 2$}

Figure:8.Check Box[6] to "tick" symbol for representation in graph.

$$
\text { Flot! }
$$

Figure:9.Command bottom[6] to plot graph. 
Thermodynamics simulation of automobile evaporative air conditioning system (evaporative test rig)

6.Objective of virtual simulation run is to calculate and plot (graphs[2]) for the final value of (Thermodynamic properties)Dry bulb temperature: $\mathrm{T}_{2}$ or $\mathrm{t}_{\mathrm{db} 2}$; Relative humidity: $\phi_{2}$; with respect to the initial input value symbol Atmosphere air temperature: $\mathrm{T}_{1}$ or $\mathrm{t}_{\mathrm{db} 1}$; Atmosphere air relative humidity: $\phi_{1} ;$ Velocity of automobile: $\mathrm{V}_{1}$; Area of evaporative test rig:A; Mass of recirculated water in water tray: $\mathrm{M}_{\mathrm{w}} ;$ Atmospheric pressure: $\mathrm{P}_{\mathrm{b}}$;

7. In addition Saturated pressure at $\left(\mathrm{t}_{\mathrm{db} 1}\right)$ dry bulb temperature: $\mathrm{P}_{1}$ orPs $\mathrm{Ps}_{1} ;$ Partial pressure of waterVapour: $\mathrm{Pv}_{1} ;$ Partial pressure of air: $\mathrm{P}_{\mathrm{a}} ;$ Specific volume of the moist air: $\mathrm{V}_{\mathrm{g}}$; Mass of atmospheric air: $\mathrm{M}_{1} ;$ (Initial)Specific humidity: $\mathrm{W}_{1} ;$ Mass of dry air: $\mathrm{M}_{\mathrm{a}} ;$ (Final)Specific humidity: $\mathrm{W}_{2} ;$ (Final)Partial pressure of water vapour:Pv $\mathrm{Pv}_{2} ;$ Saturated pressure at wet bulb temperature: $\mathrm{P}_{\mathrm{w}}=\left(\mathrm{P}_{\mathrm{w} 1}\right.$ or $\left.\mathrm{P}_{\mathrm{w} 2}\right) ;$ Wet bulb temperature: $\mathrm{T}_{\mathrm{w}}=\left(\mathrm{T}_{\mathrm{w} 1}\right.$ or $\left.\mathrm{T}_{\mathrm{w} 2}\right) ;$ Saturated pressure at $\left(\mathrm{t}_{\mathrm{db} 2}\right)$ dry bulb temperature: $\mathrm{P}_{2}$ or $\mathrm{Ps}_{1}$; value can be optionally obtained.

\section{Graphs}

Simulation[8] run result[2] and graphes[2] , by varying input feed values,.i.e. $\left(\mathrm{T}_{1} ; \mathrm{V}_{1} ; \phi_{1}\right)$ are shown as condition is as follows.

(1a).When Initial dry bulb Temperature : $30^{\circ} \mathrm{C}-35^{\circ} \mathrm{C}$;Automobile velocity:20Km/hr.,and Relative humidity: $30 \%$;

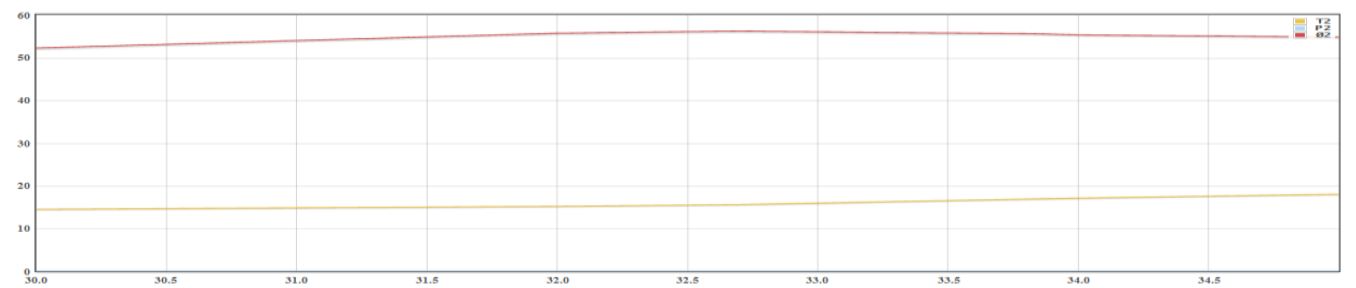

(1b).When Initial dry bulb Temperature : $30^{\circ} \mathrm{C}-35^{\circ} \mathrm{C}$;Automobile velocity:20Km/hr.,and Relative humidity:35\%;

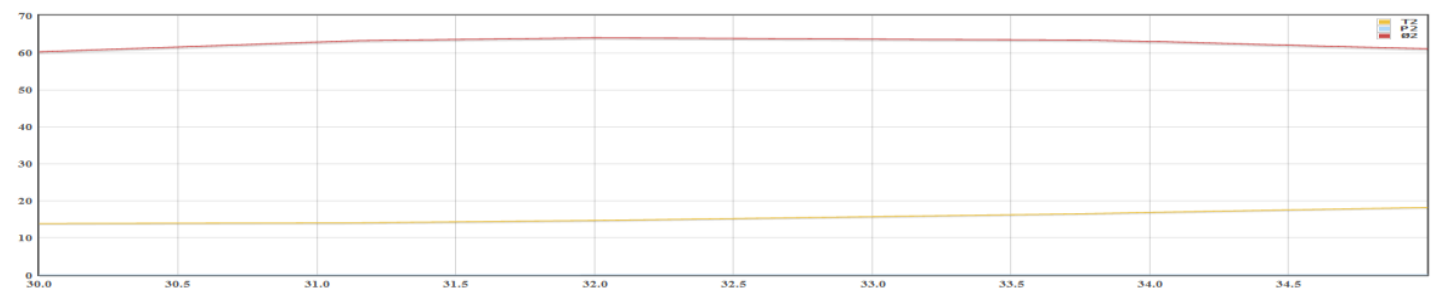

(1c). When Initial dry bulb Temperature : $30^{\circ} \mathrm{C}-35^{\circ} \mathrm{C}$;Automobile velocity:20Km/hr., and Relative humidity:40\%;

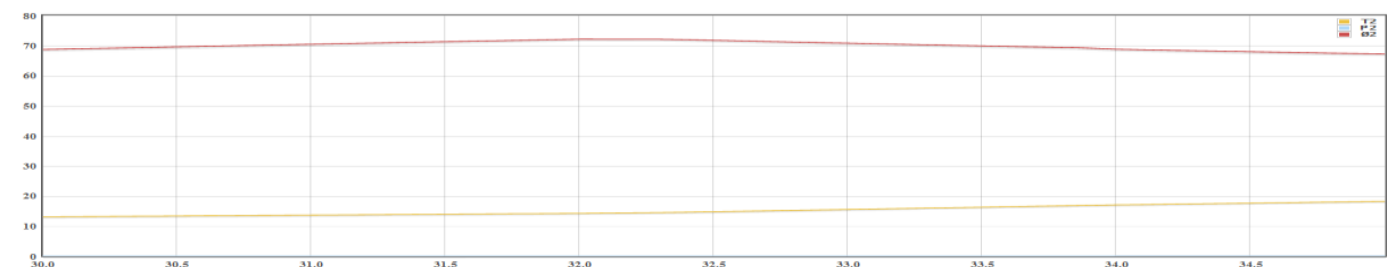

(2a). When Initial dry bulb Temperature : $35^{\circ} \mathrm{C}-40^{\circ} \mathrm{C}$; Automobile velocity: $20 \mathrm{Km} / \mathrm{hr}$., and Relative humidity:30\%;

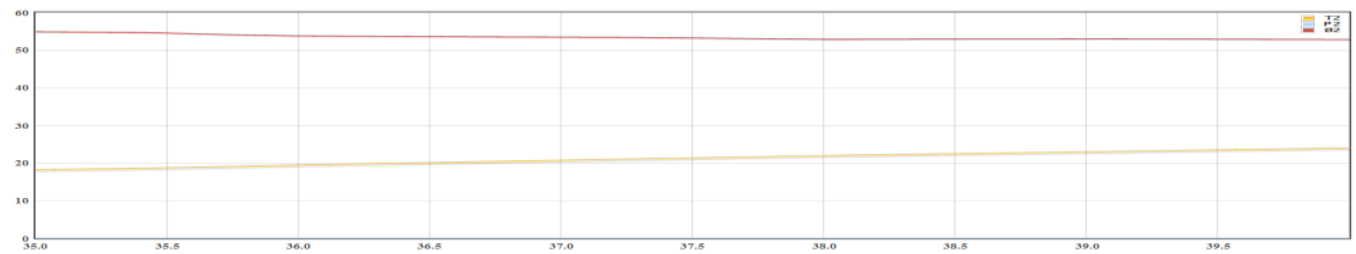

(2b). When Initial dry bulb Temperature : $35^{\circ} \mathrm{C}-40^{\circ} \mathrm{C}$; Automobile velocity: $20 \mathrm{Km} / \mathrm{hr}$., and Relative humidity: $35 \%$;

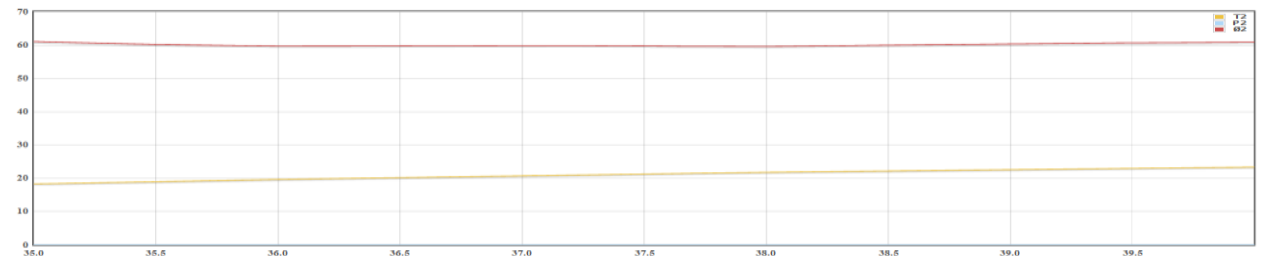

Www.iosrjournals.org 
Thermodynamics simulation of automobile evaporative air conditioning system (evaporative test rig)

(2c). When Initial dry bulb Temperature : $35^{\circ} \mathrm{C}-40^{\circ} \mathrm{C}$; Automobile velocity: $20 \mathrm{Km} / \mathrm{hr}$., and Relative humidity: $40 \%$;

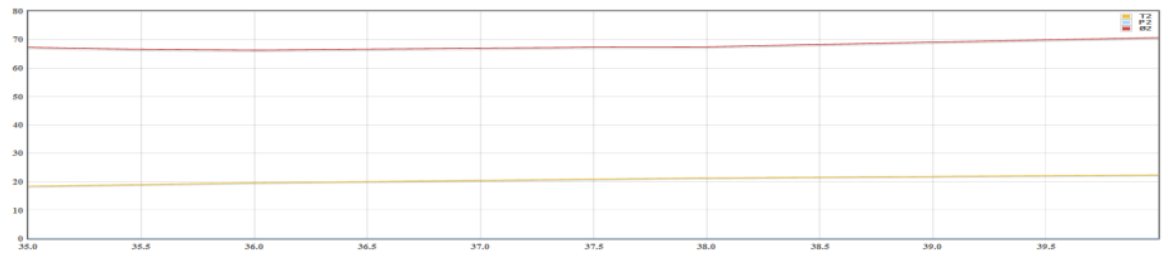

(3a). When Initial dry bulb Temperature : $40^{\circ} \mathrm{C}-45^{\circ} \mathrm{C}$; Automobile velocity: $20 \mathrm{Km} / \mathrm{hr}$., and Relative humidity:30\%;

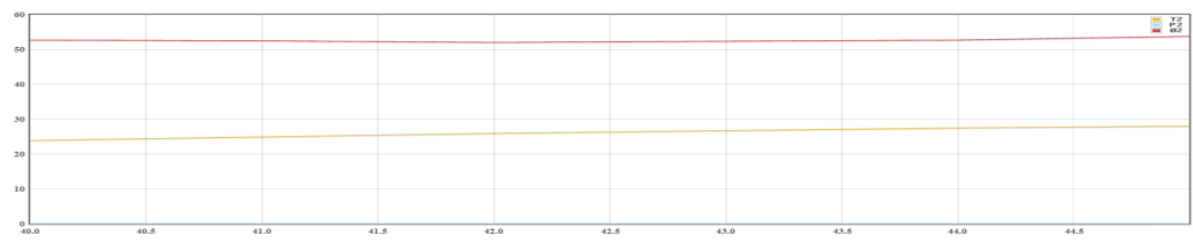

(3b). When Initial dry bulb Temperature : $40^{\circ} \mathrm{C}-45^{\circ} \mathrm{C}$; Automobile velocity: $20 \mathrm{Km} / \mathrm{hr}$.,and Relative humidity:35\%;

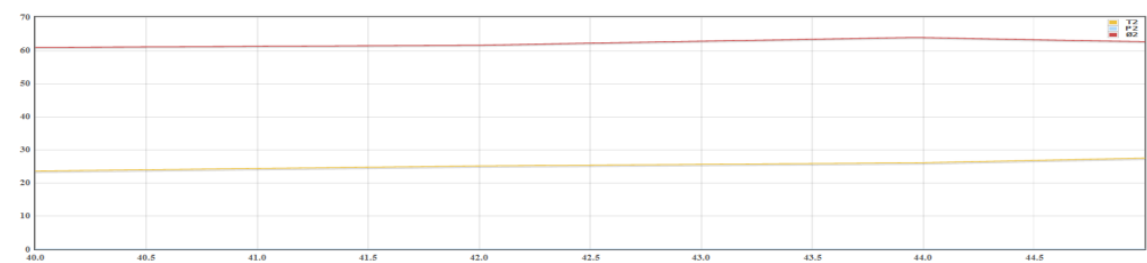

(3c). When Initial dry bulb Temperature : $40^{\circ} \mathrm{C}-45^{\circ} \mathrm{C}$; Automobile velocity: $20 \mathrm{Km} / \mathrm{hr}$.,and Relative humidity: $40 \%$;

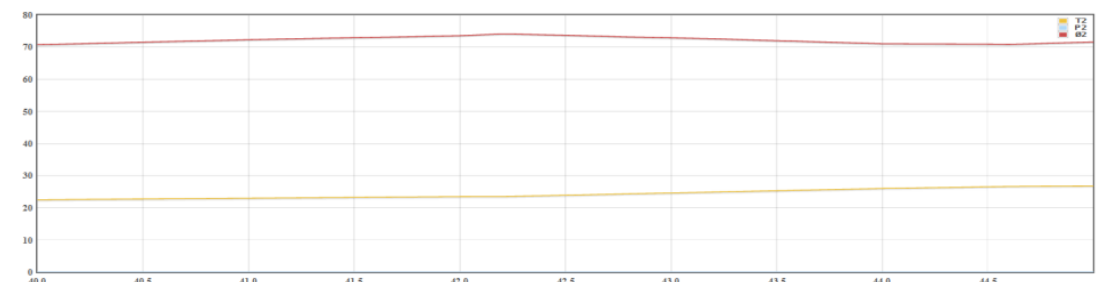

(4a).When Initial dry bulb Temperature : $45^{\circ} \mathrm{C}-50^{\circ} \mathrm{C}$; Automobile velocity: $20 \mathrm{Km} / \mathrm{hr}$.,and Relative humidity: $30 \%$;

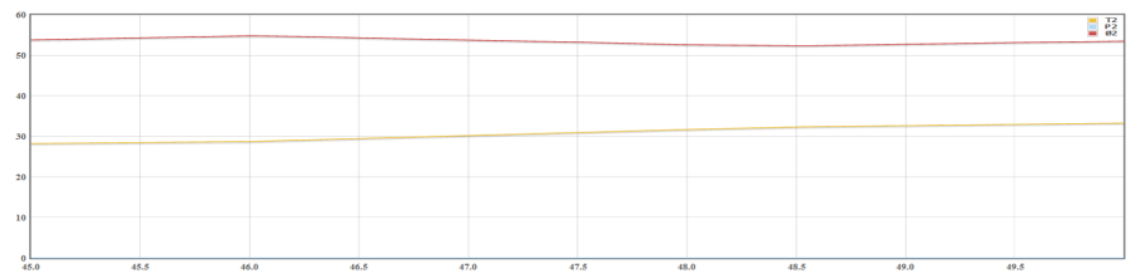

(4b).When Initial dry bulb Temperature : $45^{\circ} \mathrm{C}-50^{\circ} \mathrm{C}$; Automobile velocity: $20 \mathrm{Km} / \mathrm{hr}$., and Relative humidity: $35 \%$;

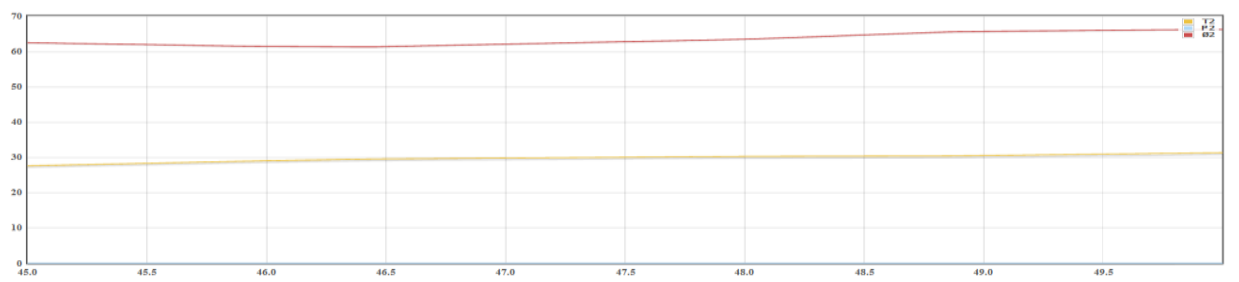

(4c).When Initial dry bulb Temperature : $45^{\circ} \mathrm{C}-50^{\circ} \mathrm{C}$; Automobile velocity:20Km/hr.,and Relative humidity:40\%; 


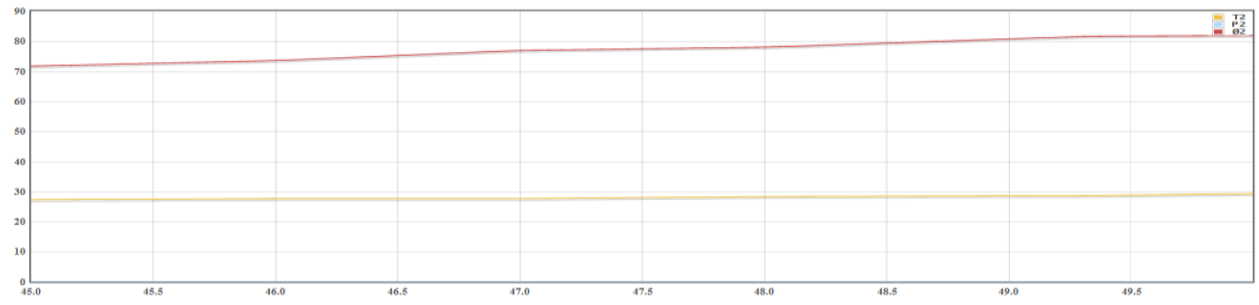

\section{Result and Discussion}

The result and discussion are as follows:

(1a).When Initial dry bulb Temperature range: $30^{\circ} \mathrm{C}-35^{\circ} \mathrm{C}$;Automobile velocity: $20 \mathrm{Km} / \mathrm{hr}$., and Relative humidity: $30 \%$; Final dry bulb temperature range: $14^{\circ} \mathrm{C}-18^{\circ} \mathrm{C}$; Final relative humidity range: $52 \%-57 \%$.

(1b).When Initial dry bulb Temperature range: $30^{\circ} \mathrm{C}-35^{\circ} \mathrm{C}$;Automobile velocity: $20 \mathrm{Km} / \mathrm{hr}$.,and Relative humidity:35\%; Final dry bulb temperature range: $14^{\circ} \mathrm{C}-18^{\circ} \mathrm{C}$; Final relative humidity range: $60 \%-62 \%$.

(1c). When Initial dry bulb Temperature range: $30^{\circ} \mathrm{C}-35^{\circ} \mathrm{C}$;Automobile velocity: $20 \mathrm{Km} / \mathrm{hr}$., and Relative humidity: $40 \%$; Final dry bulb temperature range: $12^{\circ} \mathrm{C}-18^{\circ} \mathrm{C}$; Final relative humidity range: $69 \%-67 \%$.

As the results shows that, when the velocity of automobile is $20 \mathrm{Km} / \mathrm{hr}$; relative humidity ranges from $35 \%$ to $40 \%$ and ambient air bleeding in to the ETR face duct inlet temperature range is from $30^{\circ} \mathrm{C}$ to $35^{\circ} \mathrm{C}$ (considering for the month march), this ambient air passes through cooling pad material kept in the ETR material chamber, the outlet air from the ETR to the automobile cabin, the temperature range is from $12^{\circ} \mathrm{C}$ to $18^{\circ} \mathrm{C}$ and relative humidity range is from $52 \%-69 \%$.This temperature range is an ideal result. Such an ideal results encourage enthusiasm working in the project. There is only one condition that automobile velocity limited to $20 \mathrm{Km} / \mathrm{hr}$.In spite-of restricted condition, result is supportive as outside ambient air temperature and relative humidity are moderate.

(2a). When Initial dry bulb Temperature range: $35^{\circ} \mathrm{C}-40^{\circ} \mathrm{C}$; Automobile velocity: $20 \mathrm{Km} / \mathrm{hr}$., and Relative humidity:30\%; Final dry bulb temperature range: $18^{\circ} \mathrm{C}-24^{\circ} \mathrm{C}$; Final relative humidity range: $55 \%-53 \%$.

(2b). When Initial dry bulb Temperature range: $35^{\circ} \mathrm{C}-40^{\circ} \mathrm{C}$; Automobile velocity: $20 \mathrm{Km} / \mathrm{hr}$., and Relative humidity:35\%; Final dry bulb temperature range: $18^{\circ} \mathrm{C}-23^{\circ} \mathrm{C}$; Final relative humidity range: $61 \%-61 \%$.

(2c). When Initial dry bulb Temperature range: $35^{\circ} \mathrm{C}-40^{\circ} \mathrm{C}$; Automobile velocity:20Km/hr., and Relative humidity: $40 \%$; Final dry bulb temperature range: $18^{\circ} \mathrm{C}-23^{\circ} \mathrm{C}$; Final relative humidity range: $68 \%-70 \%$.

As the result shows that, when the velocity of automobile is $20 \mathrm{Km} / \mathrm{hr}$; relative humidity ranges from $30 \%$ to $40 \%$ and ambient air bleeding in to the ETR face duct inlet temperature range is from $30^{\circ} \mathrm{C}$ to $40^{\circ} \mathrm{C}$ (considering for the month march), this ambient air passes through cooling pad material kept in the ETR material chamber, the outlet air from the ETR to the automobile cabin, the temperature range is from $12^{\circ} \mathrm{C}$ to $23^{\circ} \mathrm{C}$ and relative humidity range is from $52 \%-70 \%$.Another case when initial relative humidity $35 \%$, a constant in the final relative humidity range $(61 \%)$ is observed .This temperature range is very close to an ideal result. Such results support to the project work. There is only one condition that automobile velocity limited to $20 \mathrm{Km} / \mathrm{hr}$. This condition is supportive in two cases, they are discussed: Case1 when automobile is a car which is use for local travelling with in city, or being use for short distances of 300meter radius, example like to bring grocery items from nearby market.Case 2 when automobile is an school bus travelling in a traffic at a peak hour.

(3a). When Initial dry bulb Temperature range: $40^{\circ} \mathrm{C}-45^{\circ} \mathrm{C}$; Automobile velocity: $20 \mathrm{Km} / \mathrm{hr}$.,and Relative humidity:30\%; Final dry bulb temperature range: $22^{\circ} \mathrm{C}-28^{\circ} \mathrm{C}$; Final relative humidity range: $53 \%-54 \%$.

(3b). When Initial dry bulb Temperature range: $40^{\circ} \mathrm{C}-45^{\circ} \mathrm{C}$; Automobile velocity:20Km/hr.,and Relative humidity:35\%; Final dry bulb temperature range: $23^{\circ} \mathrm{C}-27^{\circ} \mathrm{C}$; Final relative humidity range: $61 \%-63 \%$.

(3c). When Initial dry bulb Temperature range: $40^{\circ} \mathrm{C}-45^{\circ} \mathrm{C}$; Automobile velocity:20Km/hr.,and Relative humidity: $40 \%$; Final dry bulb temperature range: $23^{\circ} \mathrm{C}-27^{\circ} \mathrm{C}$; Final relative humidity range: $70 \%-71 \%$.

As the result shows that, when the velocity of automobile is $20 \mathrm{Km} / \mathrm{hr}$; relative humidity ranges from $30 \%$ to $40 \%$ and ambient air bleeding in to the ETR face duct inlet temperature range is from $40^{\circ} \mathrm{C}$ to $45^{\circ} \mathrm{C}$ (considering for the month June), this ambient air passes through cooling pad material kept in the ETR material chamber, the outlet air from the ETR to the automobile cabin, the temperature range is from $22^{\circ} \mathrm{C}$ to $28^{\circ} \mathrm{C}$ and relative humidity range is from53\%-71\%. This temperature range is in the month of June, this make the result very ideal. Such results support to the project work. There is only one condition that automobile velocity limited to $20 \mathrm{Km} / \mathrm{hr}$. This condition is supportive in two cases, they are discussed: Case1 when automobile is a car which is use for local travelling with in city, or being use for short distances of 300meter radius, example like to bring grocery items from nearby market.Case 2 when automobile is an school bus travelling in a traffic at a peak hour. (4a). When Initial dry bulb Temperature range: $45^{\circ} \mathrm{C}-50^{\circ} \mathrm{C}$; Automobile velocity: $20 \mathrm{Km} / \mathrm{hr}$.,and Relative humidity:30\%; Final dry bulb temperature range: $28^{\circ} \mathrm{C}-33^{\circ} \mathrm{C}$; Final relative humidity range: $53 \%-53 \%$.

(4b).When Initial dry bulb Temperature range: $45^{\circ} \mathrm{C}-50^{\circ} \mathrm{C}$; Automobile velocity: $20 \mathrm{Km} / \mathrm{hr}$.,and Relative humidity:35\%; Final dry bulb temperature: $28^{\circ} \mathrm{C}-31^{\circ} \mathrm{C}$; Final relative humidity range: $62 \%-67 \%$. 
(4c).When Initial dry bulb Temperature range: $45^{\circ} \mathrm{C}-50^{\circ} \mathrm{C}$; Automobile velocity: $20 \mathrm{Km} / \mathrm{hr}$.,and Relative humidity: $40 \%$; Final dry bulb temperature range: $28^{\circ} \mathrm{C}-30^{\circ} \mathrm{C}$; Final relative humidity range: $71 \%-81 \%$.

As the result shows that, when the velocity of automobile is $20 \mathrm{Km} / \mathrm{hr}$; relative humidity ranges from $30 \%$ to $40 \%$ and ambient air bleeding in to the ETR face duct inlet temperature range is from $45^{\circ} \mathrm{C}$ to $50^{\circ} \mathrm{C}$ (considering for the month June), this ambient air passes through cooling pad material kept in the ETR material chamber, the outlet air from the ETR to the automobile cabin, the temperature range is from $28^{\circ} \mathrm{C}$ to $33^{\circ} \mathrm{C}$ and relative humidity range is from $53 \%-81 \%$.Some case initial relative humidity $30 \%$, a constant in the final relative humidity range (53\%) is observed This temperature range is in the month of June, this make the result ideal. Such results support to the project work. There is only one condition that automobile velocity limited to $20 \mathrm{Km} / \mathrm{hr}$. This condition is supportive in two cases, they are discussed: Case 1 when automobile is a car which is use for local travelling with in city, or being use for short distances of 300meter radius, example like to bring grocery items from nearby market.Case 2 when automobile is an school bus travelling in a traffic at a peak hour.

\section{Reference}

[1]. Suzuki Wagon-R (Model year-2002) image blue-print drawing access by "The-Blueprints.com", 2005.

[2]. Website address link "http://microminigames.net/sim/1/index.php".Website address link to internet explorer which open the simulation page for calculation and graph's,2012.

[3]. Simulation page created by using software tools, they are "Java script" and "Canvas HTML5". W3C standardize and regulated by Jan. 2011.

[4]. Microsoft corporation, "Paint tool of Microsoft windows-7", Home Basic, Version6.1 (Build7601: Service Pack 1), copyright 2009.

[5]. Formulation from "Chapter-4": Thermodynamic modeling. Thermodynamic simulation and experimental study of evaporative cooling system on automobile. , doctoral diss.Buit, Barkatullah university, Bhopal, M.P, India.

[6]. Drawing layout design and graph by "Canvas HTML5" ( a software language), which include simulation page with Text Box, Selection Box, Drop Down Box, Command Button or input button,.i.e,RUN and PLOT. W3C standardize and regulated by Jan 2011.

[7]. "Java script" (Common language) is used for logical mathematical or equational calculation. Our Evaporative test rig (thermodynamic analysis modeling) is coded in java script, code file are as follow: 1.Calculation file containing all formula calculation.2.Flot file is component graphing help file. Containing library of HTML data, component data.3.Index.php file to support "HTML5" for simulation page.4.Portable network graph images) file to support diagram of car with E.T.R. W3C standardize and regulated by Jan. 2011

[8]. All the simulation is created with software tool's “canvas HTML5 and, Java script”.W3C standardizes and regulated by Jan. 2011.

[9]. C.A.D. model done in "I-DEAS.11.0", 2011

[10]. ANSYS Inc.:"Theory Guide-ANSYS FLUENT 12.0”, Copyright 2009, and ISO- 9001: April 2009. 